EPiC Series in Language and Linguistics
Volume 3, 2018, Pages 117-123
LSP in Multi-disciplinary contexts of
Teaching and Research. Papers from the
16th International AELFE Conference

\title{
Firm Performance: Does Mastering a Foreign Language Matter?
}

\author{
Remedios Hernández Linares ${ }^{\mathrm{a}}$, María José Naranjo Sánchez ${ }^{\mathrm{b}}$, Héctor Sánchez \\ Santamaría $^{\mathrm{c}}$, Mercedes Rico García ${ }^{\mathrm{d}}$, Laura V. Fielden Burns ${ }^{\mathrm{e}}$, J. Enrique \\ Agudo Garzón ${ }^{\mathrm{f}}$
}

\author{
${ }^{a}$ Department of Financial Economics and Accounting, University of Extremadura, Universitary Center of Mérida, Av. Santa \\ Teresa de Jornet, 28, 06800 Mérida (Badajoz), Spain \\ ${ }^{b}$ Department of English Philology, Faculty of Medicine, University of Extremadura, Av. Elvas, s/n, 06006 Badajoz, Spain \\ ${ }^{c}$ Department of Computer Systems and Telematics Engineering, Universitary Center of Mérida, Av. Santa Teresa de Jornet, 28, \\ 06800 Mérida (Badajoz), Spain \\ ${ }^{d}$ Department of English Philology, University of Extremadura, Universitary Center of Mérida, Av. Santa Teresa de Jornet, 28, \\ 06800 Mérida (Badajoz), Spain \\ ${ }^{e}$ Department of Didactics of Social Science, Language and Literature, Facultad de Formación del Profesorado, University of \\ Extremadura, Avenida de la Universidad, s/n, 10003 Cáceres, Spain \\ ${ }^{f}$ Dirección General de Personal Docente, Consejería de Educación y Empleo de la Junta de Extremadura Avda. Valhondo s/ $n$ \\ Edificio III Milenio, Módulo 5, $3^{a}$ planta 06800 Mérida (Badajoz), Spain
}

\begin{abstract}
Over the last twenty years the impact of language in international and multinational companies has attracted significant scholarly attention, which is reflected in the growing literature. However, and despite the fact that small and medium enterprises (SMEs) constitute the engine of numerous economies worldwide, the impact of foreign languages on SMEs' performance remains understudied. This is especially intricate because, considering that SMEs often have fewer resources, the commitment of such resources to language acquisition and foreign language education can only be justified in the case of improved performance. To address this gap, the objective of our research aims to get insights whether and how the domain of a foreign language (mainly English) affects SMEs' performance. For this purpose, we perform an exploratory empirical study based on data collected through a telephone questionnaire during the first semester of 2017. A group of private Spanish SMEs constitutes our sample. Our work presents the results of the statistical analysis of these primary data, and contributes to a more nuanced perspective on language utility for organizational performance.
\end{abstract}

Keywords: performance, SMEs, foreign language.

A. Curado (ed.), AELFE2017 (EPiC Series in Language and Linguistics, vol. 3), pp. 117-123 


\section{Contextualization and objectives}

Small and medium enterprises (SMEs) are an essential component of the European economy. They make up an impressive $99 \%$ of the European businesses, while providing $85 \%$ of all new jobs (Hagen, Brouet, \& Ortmans, 2011). The extent to which they can survive in an ever-changing economy is often conditioned by the success of their internationalization efforts, which are in turn often dependent on successful foreign language use, as numerous studies note (e.g., Hagen, Brouet, \& Ortmans, 2011, p. 13).

Though losses are difficult to calculate, a previous report from the European Commission, (Hagen et al., 2006) in a sample of 1964 European SMEs found that $37 \%$ had actually lost a contract due to language difficulties, a loss worth between 8 million and 13.5 million euros. The importance of linguistic competence to these businesses is also evident, for example, at the institutional level in the EU, as the formation of the Business Platform for Multilingualism signals (BPfLM). The BPfLM "constitutes the first attempt, at the European level, to encourage and enable stakeholders from various sectors to reflect on, develop recommendations for, and take concrete action with regard to improving business performance and employability through language strategies" (BPfLM, 2011).

Over the last twenty years, the precise impact of language in international and multinational companies has attracted significant scholarly attention, which is reflected in the growing literature (e.g., Brannen, Piekkari, \& Tietze, 2014). However, and despite the fact that small and medium enterprises (SMEs) constitute the engine of numerous economies worldwide as mentioned, the impact of foreign languages on SMEs' performance remains understudied (Lauring \& Selmer, 2011). This is especially curious because, considering that SMEs often have fewer resources (Zahra, Hayton, \& Salvato, 2004), the commitment of such resources to language acquisition and foreign language education can only be justified in the case of improved performance. To address this gap, the objective of our research is to know whether and how the domain of a foreign language (mainly English) affects SMEs' performance.

\section{Framework}

According to the RBV, firms possess a heterogeneous, firm-specific bundle of resources, not perfectly mobile, and which are valuable, rare, inimitable and non-substitutable (VRIN) (Barney, 1991). Thus, a firm enjoys a superior performance over its competitors when it possesses VRIN, leading to efficiency advantages and entrepreneurial rents (Barney, 1991; Wang \& Ahmed, 2007). In this context, we state that one of these resources can be the domain of a foreign language. English is the global language of business since more and more multinational companies are mandating English as the common corporate language, and knowing a language also involves understanding a culture. But adopting a global language policy is not easy. Many companies may feel at a disadvantage if their English competences are not good enough. While companies work hard to remain competitive in a market, employees also need to master the ability to communicate effectively, including the ability to speak and understand other languages and cultures (University of Kent, 2013). But to survive in a global economy, companies must overcome language barriers. There are different factors a companies may consider when deciding to operate at international level or with a foreign company. Being able to communicate business strategies can be challenging and identifying the importance of language is crucial to its success. 
Though this topic is still under-research, the domain of a foreign language can be considered a strategic resource, and in line with previous studies (e.g. Stoian, Rialp, \& Rialp, 2011), it is our purpose to find a positive association between the level of competence in a foreign language and SMEs performance.

Given that smaller firms have a lesser variety of options than bigger companies in terms of resources and capabilities, the domain of a foreign language (and the commitment of resources required for the language acquisition and formation) is justified in case of improved performance, reason by which it is necessary to open this line of research.

\section{Method}

\subsection{Sample}

The data for this study was collected using a survey instrument, consistent with recent literature (e.g., Cruz \& Nordqvist, 2012). Similar to other researchers, we define SMEs as non-listed private companies ranging from 10 to 249 employees (e.g., Naldi et al., 2007). Our target firms came from the SABI database (System of Iberian Balance Sheets) which has been used earlier in literature (e.g., Cruz, Gómez-Mejía, \& Becerra, 2010). One hundred and thirty surveys were fully answered by the top-management-team from companies randomly selected from SABI, resulting in a final response rate of $21.09 \%$.

\subsection{Measures}

All variables were measured using Likert-type scales with a five-point response format, ranging from "strongly disagree" to "strongly agree", except industry (coded as 1=agriculture, 2=manufacturing, $3=$ construction, $4=$ services), zone (coded as 1= Cáceres, 2= Rest of Spain), and performance items, whose five-point response format ranged from "much worse" to "much better."

The dependent variable used was performance. Performance scale employed was taken from Arend (2013), and its reliability was studied via Cronbach alpha, which equals 0.843 , surpassing the threshold point of 0.7 (Nunally, 1978). Perceptual performance judgments were used to assess SMEs performance. Subjective measures of performance have been frequently used in strategy research (e.g., Real, Roldán, \& Real, 2014), since they yield more holistic evaluations and capture more than a single performance element (Rodríguez, Carrillat, \& Jaramillo, 2004). There is also a strong correlation between objective and subjective performance measures (Dess \& Robinson, 1984). Considering performance an inherently multidimensional construct (Cameron, 1978), we asked respondents to compare their organization with that of their competitors in terms of financial and competitive performance, with respect to ROA; growth in sales; market share; quality of products, services, or programs; and development of new products, services, or programs. Fivepoint responses ranged from "much worse" to "much better."

The independent variables utilized were mastery of a foreign language (mainly English) in order to: (1) introducing products into international markets (contacts with clients, suppliers, etc.); (2) writing personal communication (letters, fax, e-mails); (3) oral personal communication; (4) attendance at international commercial conferences and events; (5) attendance at meetings that require a language different from Spanish; and (6) communication via social networks.

Finally, we controlled for the influence of industry because businesses in different industries may exhibit different organizational and environmental characteristics, which, in turn, might 
influence their performance (Wiklund \& Sepherd, 2005). Specifically, we controlled the industry following NACE coding (statistical classification of economic activities in the European Community). We also controlled for zone because this study was partially supported by the Diputación de Cáceres, so we classified all SMES in firms located in the Cáceres province or the rest of Spain.

\section{Results and discussion}

In our research, correlation coefficients were high $(<0.845)$, reason by which we checked variance inflation factors (VIF) and condition indexes. The resulting variance inflation factors $(<$ 1.037) and highest condition index $(<4.898)$ were well below the suggested thresholds (Hair, Anderson, Tatham, \& Black, 1998). Therefore, multicollinearity does not appear to be a serious concern (Hair et al., 1998), however, the variables were converted to z scores (Aiken \& West, 1991).

Furthermore, since all answers were given by the same person, the possibility of a common method bias was addressed by Harman's (1967) single-factor test using the procedure suggested by Podsakoff and Organ (1986), and applied by recent studies (e.g., Walter, Kellermanns, \& Lechner, 2012). Thus, as suggested by Podsakoff and Organ (1986), all items of the independent, dependent, and control variables were entered into a factor analysis, and four factors with eigenvalues $>1.0$ were identified accounting for $64.942 \%$ of the variance. As the first factor $(31.070 \%)$ does not explain the majority of the variance, no single method factor emerged.

\begin{tabular}{lcc} 
Table 1. Results of linear regression analysis: two models & \\
& & \\
\hline Variables & Model 1 & Model 2 \\
\hline Controls: & 0.087 & 0.066 \\
Industry & -0.087 & -0.054 \\
Zone & & \\
\hline Independent variables: & & -0.055 \\
Introduction products in international markets & & -0.078 \\
Written personal communication & & 0.089 \\
Oral personal communication & & $0.199^{\dagger}$ \\
Attendance to congresses and international events & & $-0.378^{* *}$ \\
Attendance to meetings demanding a foreign language & & 0.139 \\
Communication via social networks & 0.046 & $0.146^{*}$ \\
\hline$R^{2}$ & 0.046 & 0.192 \\
$R^{2}$ & 0.078 & 0.105 \\
Adjusted $R^{2}$ & 1.928 & $2.197^{*}$ \\
$F$ & & \\
\hline
\end{tabular}

${ }^{\sharp}$ Standardized regression weights; ${ }^{\dagger} \mathrm{p}<.10 ; * \mathrm{p}<.05 ;{ }^{* *} \mathrm{p}<.01$

The model was tested by using multiple regression analysis; results appear in Table 1. In Model 1, two control variables were included, but none of them were significantly related to SME performance: industry ( $b=0.087$, n.s.), and zone $(b=-0.087$, n.s. $)$. We entered the six independent 
variables in Model 2. A significant change in $\mathrm{R}^{2}$ was observed $\left(\Delta \mathrm{R}^{2}=.146, \mathrm{p}<.001\right)$, but only two variables were significantly associated to SME performance: foreign language for attending meetings, and foreign language for attending conferences and international events. In our view, the fact that the rest of variables has not been found to be significantly associated to organizational performance, could be explained because the level of language for these purposes has become a necessary condition to survive in global markets, but given that all firms should have acquired these conditions, they do not constitute a value and rare resource with capacity to influence the SMEs firm. However, the foreign language for attending meetings which demand a foreign language $(b=-0.378, p<.005)$ had a significant negative effect on SMEs performance. This result is especially relevant because it goes against our initial hypothesis that personal interactions (meeting) facilitate building commercial relationships, offering the chance of better satisfying the needs of clients and other stakeholders. While the usage of a foreign language to attend conferences and international events $(b=.199, \mathrm{p}<.001)$ had a partially significant positive effect on SMEs performance, which seems to indicate that the domain of a foreign language for addressing this type of events makes it easier to SMEs to extract their potential benefits. Remaining independent variables were not found to have a significant effect on SMEs performance.

\section{Conclusion}

Convinced that business communication and language go hand in hand in order for companies to achieve success with it potential consumers, determining the importance of language in business communication has been the general goal of this research. Based on an empirical study with 130 Spanish SMEs, we found that the foreign language for attendance at conferences and international events had a partially significant positive effect on SMEs performance. This positive association corroborates previous studies' in this field, since "lack of speaking skills" arose in the ELAN study (Hagen et al., 2006) as one of the main reasons listed by which companies lose trade. However, the level in a foreign language to attend professional \& business meetings had a significant negative effect on SMEs performance. These contradictory findings are especially intricate, given that both of them involve using foreign language for a productive task, in particular, speaking, either in a meeting or at conferences or fairs. The difference between these types of speaking tasks does not seem to be relevant, yet for SMEs, it may be according to the results. One task is local and particular, involving a certain degree of necessary nuance, where speaking skills in a foreign language at meetings might make or break a deal. On the other hand, speaking skills in use at a conference or international event might be less nuanced and more global, involving an overall representation of the company. In this sense, the oral skills needed at a conference are less urgent and more universally applicable than those needed to fine-tune negotiations in a meeting between interested parties. In our view these results require further study. 


\section{Acknowledgements}

We would like to acknowledge the financial support of the University of Extremadura (Young Researchers Strategic Plan), subprogram from Diputación de Cáceres (reference: Acción VII-14).

\section{References}

Aiken, L.S., \& West, S.G. (1991). Multiple Regression: Testing and Interpreting Interactions. Newbury Park, CA: Sage. Arend, R.J. (2013). Ethics-focused dynamic capabilities: a small business perspective. Small Business Economics, 41(1), $1-24$.

Barney, J. (1991). Firm resources and sustained competitive advantage. Journal of Management, 17(1), 99-120.

Brannen, M. Y., Piekkari, R., \& Tietze, S. (2014). The multifaceted role of language in international business: Unpacking the forms, functions and features of a critical challenge to MNC theory and performance. Journal of International Business Studies, 45(5), 495-507.

Bussiness Platform for Multilingualism(2011, June). Report for the period September 2009- June 2011. European Commission. $\quad$ Retrieved June $\quad 7$, from http://ec.europa.eu/dgs/education_culture/repository/languages/library/documents/business_en.pdf

Cameron, K. (1978). Measuring organizational effectiveness in institutions of higher education. Administrative Science Quarterly, 23(4), 604-632.

Cruz, C., Gomez-Mejia, L. R., \& Becerra, M. (2010). Perceptions of benevolence and the design of agency contracts: CEO-TMT relationships in family firms. Academy of Management Journal, 53(1), 69-89.

Cruz, C., \& Nordqvist, M. (2012). Entrepreneurial orientation in family firms: A generational perspective. Small Business Economics, 38(1), 33-49.

Dess, G. G., \& Robinson, R. B. (1984). Industry effects and strategic management research. Journal of Management, 16(7), 7-27.

Hagen, S., Foreman-Peck, J., Davila-Philippon, S., Nordgren, B., \& Hagen, S. (2006). "Effects on the European Economy of Shortages of Foreign Language Skills in Enterprise (ELAN Study): An analysis of the use of languages and the effect of linguistic deficiencies in European exporting businesses in 29 countries", in European Commission Brussels and National Centre for Languages (CILT), London: Final Rep, 2006.

Hagen, S., Brouet, O., \& Ortmans, F. (2011, April). Report on Language Management Strategies and Best Practice in European SMEs: The PIMLICO Project. Brussels: European Commission, DGEAC.

Harman, H. H. (1967). Modern Factor Analysis. Chicago, IL: University of Chicago Press.

Lauring, J., \& Selmer, J. (2011). Multicultural organizations: common language, knowledge sharing and performance. Personnel Review, 40(3), 324-343.

Naldi, L., Nordqvist, M., Sjöberg, K., \& Wiklund, J. (2007). Entrepreneurial orientation, risk taking, and performance in family firms. Family Business Review, 20(1), 33-47.

Nunally, J. C. (1978). Psychometric Theory. New York: McGraw-Hill.

Podsakoff, P.M., \& Organ, D.W. (1986). Self-reports in organizational research: Problems and perspectives. Journal of Management, 12(4), 531-544.

Real, J. C., Roldán, J. L., \& Leal, A. (2014). From entrepreneurial orientation and learning orientation to business performance: analysing the mediating role of organizational learning and the moderating effects of organizational size. British Journal of Management, 25(2), 186-208.

Rodríguez, C., Carrillat, F. A., \& Jaramillo, F. (2004). A meta-analysis of the relationship between market orientation and business performance: evidence from five continents. International Journal of Research in Marketing, 21(2), 179-200.

Stoian, M. C., Rialp, A., \& Rialp, J. (2011). Export performance under the microscope: A glance through Spanish lenses. International Business Review, 20(2), 117-135.

University of Kent (2013).What are the top ten skills that employers want? Retrieved June 7, from http://www.kent.ac.uk/careers/sk/top-ten-skills.htm

Walter, J., Kellermanns, F.W., \& Lechner, C. (2012). Decision making within and between organizations rationality, politics, and alliance performance. Journal of Management, 38(5), 1582-1610.

Wang, C.L. \& Ahmed, P.K. (2007). Dynamic capabilities: A review and research agenda. International Journal of Management Reviews, 9(1), 31-51.

Wiklund, J., \& Shepherd, D. (2005). Entrepreneurial orientation and small business performance: a configurational approach. Journal of Business Venturing, 20(1), 71-91. 
Zahra, S. A., Hayton, J. C., \& Salvato, C. (2004). Entrepreneurship in family vs. non-family firms: A resource- based analysis of the effect of organizational culture. Entrepreneurship Theory and Practice, 28(4), 363-381. 